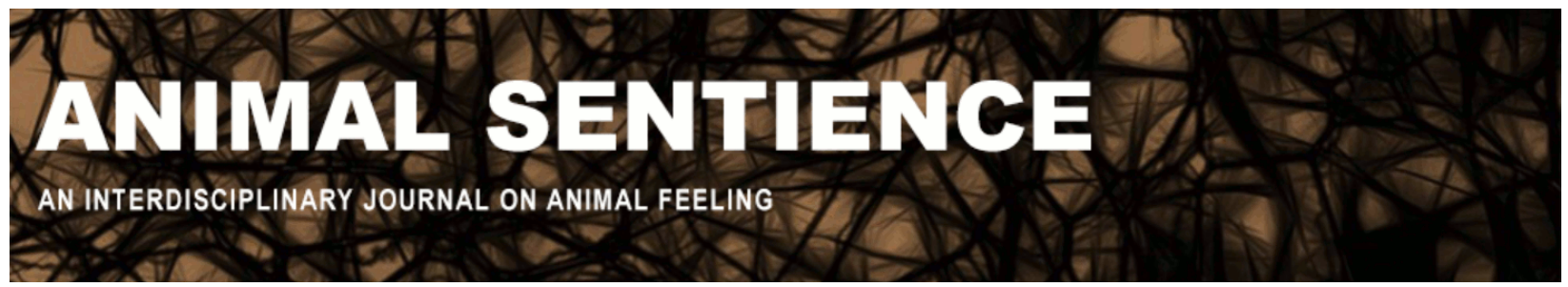

Balcombe, Jonathan (2016) Cognitive evidence of fish sentience. Animal Sentience 3(2)

DOI: $10.51291 / 2377-7478.1059$

Date of submission: 2015-11-02

Date of acceptance: 2015-12-11

(c)

This article has appeared in the journal Animal

Sentience, a peer-reviewed journal on animal

cognition and feeling. It has been made open access,

free for all, by WellBeing International and deposited

in the WBI Studies Repository. For more information,

please contact

wbisr-info@wellbeingintl.org.

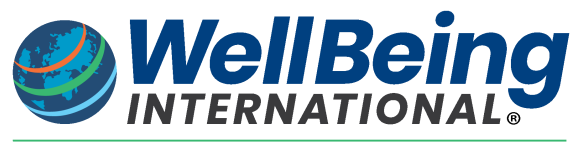

SOLUTIONS FOR PEOPLE, ANIMALS AND ENVIRONMENT 


\title{
Cognitive evidence of fish sentience
}

Commentary on Key on Fish Pain

\author{
Jonathan Balcombe \\ Institute for Science and Policy \\ Humane Society of America
}

\begin{abstract}
I present a little-known example of flexible, opportunistic behavior by a species of fish to undermine Key's (2016) thesis that fish are unconscious and unable to feel. Lack of a cortex is flimsy grounds for denying pain to fish, for on that criterion we must also then deny it to all nonmammals, including birds, which goes against scientific consensus. Notwithstanding science's fundamental inability to prove anything, the precautionary principal dictates that we should give the benefit of the doubt to fish, and the state of the oceans dictates that we act on it now.
\end{abstract}

Jonathan Balcombe jbalcombe@humanesociety.org is Director for Animal Sentience at the Humane Society Institute for Science and Policy in Washington, DC. He has published over 50 scientific papers on animal behavior and animal protection. Jonathan has written four books, with the most recent, What a Fish Knows, scheduled for publication in 2016. www.jonathanbalcombe.com

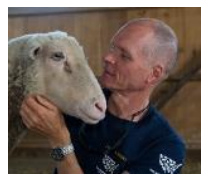

In January 2014 at Schroda Dam, a man-made lake in Limpopo Province, South Africa, scientists documented on film something remarkable and surprising. As a trio of barn swallows skimmed just above the water, a Tigerfish (Hydrocynus vittatus) leapt up and snatched one of the birds out of midair. The swallow capture wasn't an isolated incident. Unconfirmed observations of bird-catching by these freshwater predatory fish date back to the 1940s, and the research team that published the latest study witnessed up to 20 swallow-snatching incidents per day over a 15-day period (O’Brien, Jacobs, Evans \& Smit 2014).

Is this bird-hunting behavior the work of a brain-dead thing without feelings - as Key (2016) would claim? Or is it the product of an intelligent, aware, flexible animal that can plan an ambush? That is a misleading dichotomy, for a fish does not need to be guileful to discredit Key's radical hypothesis; it has only to be able to experience something.

But the Tigerfish demonstrate so much more than that. Their hunting is nuanced and flexible. They use two distinct attack methods, either (1) pursuing the bird along the surface then launching to catch it, or (2) making a vertical attack from at least half a meter below the surface. Both methods require physical skill, keen timing, and in the case of method 2, compensation for light refraction at the surface (O'Brien et al. 2014).

Birds are not a mainstay on the Tigerfish menu. These Tigerfish appear to be hunting them opportunistically, and possibly out of desperation. Tigerfish were introduced to Schroda in 2003 to help boost their dwindling populations elsewhere. But they failed to flourish in the relatively sterile man-made waters, and by 2009 , larger specimens were observed to be in poor physical 
condition. They spent more time foraging than other local Tigerfish, apparently due to food scarcity in the lake (O'Brien, Bulfin, Husted \& Smit 2012). If hunting swallows is an opportunistic behavioral adjustment to avert starvation, then it says a good deal about the resourcefulness of these fish. I can imagine a Tigerfish thinking of swallows as they prepare their next hunting foray.

Swallow-hunting by Tigerfish is just one of many examples of fish behavior that demonstrate thinking and feeling. As the body of scientific discoveries of fish thinking and feeling accumulates, there are hundreds of examples one could choose from to challenge the view that fish are insentient. Among them are tool use by Wrasses (Bernardi 2012), cooperative hunting between Groupers and Moray Eels (Vail, Manica \& Bshary 2013), observational learning by Lemon Sharks (Guttridge, van Dijk, Stamhuis, Krause, Gruber \& Brown 2013), massage-seeking to relieve stress in Surgeonfish (Soares et al. 2011), and audience effects in Mollies (Makowicz, Plath, \& Schlupp 2010). As I was writing this commentary, I learned of a new study demonstrating the first reported case of cooperative vigilance in fish: Rabbitfish of four species who forage in pairs, taking turns to look out for danger while the other gets to poke around the reef crevices in relative peace (Brandl \& Bellwood 2015).

Do these examples "prove" fish sentience and awareness? In the strictest, academic sense, they do not prove it, any more than I can prove that Key is a human and not a clever robot, or that birds are sentient, cognitive creatures. But common sense, bolstered by substantial empirical evidence, emphatically supports these capacities. The case of birds is especially relevant, because scientific consensus holds that they are sentient, even though their brains lack the mammalian cortex that Key and others believe is so critical to feeling pain. Key does not address this inconsistency in his target article.

Needless to say, the question of fish sentience is not a trifling academic debate. The implications are enormous. With anywhere from 300 billion to over two trillion individual fish being killed by us every year - most by deplorable means such as crushing, decompression, asphyxiation or exsanguination - we have a lot of moral accounting to do if the fish are indeed sentient (Cooke \& Cowx 2004, Mood 2010).

A practical resolution to any doubt is to apply the precautionary principle, which in this case goes something like this: if denying fish pain might cause harm and suffering to fish, then the burden of proof falls on those who deny it. Given the sad state of the oceans, which we have been overfishing and using as a garbage dump for centuries, it's high time we stepped up and got serious about addressing pain and suffering for those who live there (Sea the Truth 2010).

\section{References}

Bernardi, G. 2012. The use of tools by wrasses (Labridae). Coral Reefs 31:39-39. 
Brandl, S.J. \& Bellwood, D.R. 2015. Coodinated vigilance provides evidence for direct reciprocity in coral reef fish. Nature Scientific Reports. Accessed 30 September 2015 at http://www.nature.com/articles/srep14556

Cooke, S.J. \& Cowx, I.G. 2004. The role of recreational fisheries in global fish crises. BioScience 54:857-859.

Guttridge, T.L., van Dijk, S., Stamhuis, E.J., Krause, J., Gruber, S.H. \& Brown, C. 2013. Social learning in juvenile lemon sharks, Negaprion brevirostris. Animal Cognition 16:55-64.

Key, B. (2016). Why fish do not feel pain. Animal Sentience 2016.3.

Makowicz, A.M., Plath, M. \& Schlupp, I. 2010. Using video playback to study the effect of an audience on male mating behavior in the Sailfin molly (Poecilia latipinna). Behavioural Processes 85:36-41.

Mood, A. 2010. Worst things happen at sea: the welfare of wild-caught fish. Accessed 23 May 2013 at www.fishcount.org.uk

O’Brien, G.C., Bulfin, J.B., Husted, A. \& Smit, N.J. 2012. A comparative behavioural assessment of an established and new tigerfish (Hydrocynus vittatus) population in two artificial impoundments in the Limpopo catchment, Southern Africa. African Journal of Aquatic Sciences 37:253-263.

O’Brien, G.C., Jacobs, F., Evans, S.W. \& Smit, N.J. 2014. First observation of African tigerfish Hydrocynus vittatus predating on barn swallows Hirundo rustica in flight. Journal of Fish Biology 84:263-266. doi:10.1111/jfb.12278

Sea the Truth. 2010. [documentary film, $1 \mathrm{hr}$. Director: Claudine Everaert. Accessed 30 September 2015 at https://www.youtube.com/watch?v=RECi3ixZj-o

Soares, M.C., Oliveira, R.F., Ros, A.F., Grutter, A.S. \& Bshary, R. 2011. Tactile stimulation lowers stress in fish. Nature Communications 2:534.

Vail, A.L., Manica, A. \& Bshary, R. 2013. Referential gestures in fish collaborative hunting. Nature Communications 4:1765. doi:10.1038/ncomms 2781 